Volume: 06, Issue: 06 "November-December 2020"

\title{
ELEVATED PHOSPHORUS ENHANCES PRODUCTIVITY AND REDUCES COMMON DISEASES OF MULBERRY PLANT
}

\author{
Faruque Ahmed ${ }^{1}$, Rafia Sultana ${ }^{1}$ and Md. Toufiq Iqbal ${ }^{2 *}$ \\ ${ }^{1}$ Department of Mulberry, Bangladesh Sericulture Research and \\ Training Institute, Rajshahi 6207, Bangladesh. \\ ${ }^{2}$ Department of Agronomy and Agricultural Extension, \\ University of Rajshahi, Rajshahi 6205, Bangladesh. \\ *Corresponding author
}

DOI: https://doi.org/10.51193/IJAER.2020.6610

\begin{abstract}
Elevated phosphorus (P) may improve productivity and suppresses common diseases of mulberry plant. This study was undertaken to quantify elevated level of $\mathrm{P}$ supply for mulberry cultivation with respect to the age of mulberry plant. A field experiment was conducted at Bangladesh Sericulture Research and Training Institute (BSTRI), Rajshahi, Bangladesh to find out the effect of elevated $\mathrm{P}$ on growth, leaf yield, leaf quality, nutrient uptake and infestation of common diseases of mulberry plant. Six levels of $\mathrm{P}(0,40,80,120,160$ and $200 \mathrm{~kg} / \mathrm{ha} / \mathrm{yr})$ along with BSRTI recommended basal doses (RBD) of nitrogen $(\mathrm{N})$ and potassium $(\mathrm{K})$ through 4 split doses were applied during mulberry plant production. Result showed that the leaf yield was increased by $71.67 \%$ for 6-10 year's plant due to application of $160 \mathrm{~kg} / \mathrm{ha} / \mathrm{yr} \mathrm{P}$ with four split doses through BSRTI recommended basal doses of $\mathrm{N}$ and $\mathrm{K}$. Similarly, the leaf quality parameters viz: moisture (\%), Chlorophyll-a, Chlorophyll-b, crude protein (\%), soluble carbohydrate $(\%)$, total sugar $(\%)$ and reducing sugar $(\%)$ except total mineral $(\%)$ were increased by $11.63,5.13,9.09,44.00,42.21,30.62$ and $18.49 \%$ respectively for the same treatment. The average incidence percentages of common disease like powdery mildew, leaf spot and leaf rust diseases were reduced by $26.77,62.07$ and $38.54 \%$ respectively under the same fertilizer management. This study concluded that the elevated P enhances mulberry leaf yield and quality as well as suppresses the common diseases incidence of mulberry plant.
\end{abstract}

Keywords: chlorophyll, leaf quality, powdery mildew, leaf spot, leaf rust, silk cocoon 
International Journal of Agriculture and Environmental Research

ISSN: 2455-6939

Volume: 06, Issue: 06 "November-December 2020"

\section{INTRODUCTION}

Mulberry is a deep rooted perennial plant mainly cultivated to harvest leaves for rearing of silkworms (Jian et al.2012). Improvement in larval and cocoon characters of the silkworms has been witnessed with the increase in the nutritional status of mulberry leaf (Venkataramu 1986). The better growth and development of silkworm larvae as well as good quality cocoons when fed on nutritionally enriched mulberry leaves (Seki et al. 1959). Hence, quality of mulberry leaf is one of the basic prerequisite of sericulture and plays a pivotal role for successful silkworm cocoon crop (Guttierrez et al. 1997).

Phosphorus (P) has a positive response on mulberry crops under irrigated condition (Kasiviswanathan and Iyengar, 1966; Ray et al. 1973). The $\mathrm{P}$ influences the yield and leaf quality of mulberry plant (Bose et al. 2009). The $\mathrm{P}$ is also the most important plant nutrient that has a key role in the growth, metabolism and development of mulberry plants (Gallegos-Cedillo et al. 2016).

Mulberry plant is affected by a number of diseases caused by fungi, bacteria, viruses and nematodes (Sengupta et al. 1990; Yashihiko 1995). Khan et al. (2004) reported that in Kashmir valley among the Mulberry diseases like leaf spot and powdery mildew are the major foliar diseases of mulberry which are the impediments in the production of quality leaf feed (Khan et. al. 2004). Powdery mildew, leaf spot and leaf rust are the major foliar fungal diseases which reduce the leaf production as well as depletion of leaf quality of mulberry plant (Rabbel 1995). Therefore, it is essential to investigate the impact of elevated phosphorus on common diseases of mulberry plant.

There is no study available to quantify elevated $\mathrm{P}$ effect on mulberry productivity and suppression of common disease during mulberry growth period. The present study quantifies the optimum level of $\mathrm{P}$ fertilizer need to be supplied in soil along with BSRTI, recommended basal dose (RBD) of $\mathrm{N}$ and $\mathrm{K}$ to get maximum mulberry leaf yield and quality. Therefore, studies were carried out to see the effect of different levels of phosphorus on growth attributes, leaf yields, leaf quality, nutrients uptake and common diseases of mulberry plant. It was hypothesized that the application of different levels of $\mathrm{P}$ with recommended basal doses of $\mathrm{N}$ and $\mathrm{K}$ will be enhanced the leaf yield, quality as well as suppress the infestation of common diseases of mulberry plant.

\section{MATERIALS AND METHODS}

\subsection{Experimental site}


An experiment was conducted in the experimental field of the Bangladesh Sericulture Research and Training Institute (BSRTI), Rajshahi, Bangladesh which is located at the $24^{\circ} 22^{\prime} 29^{\prime \prime} \mathrm{N}$ and $88^{\circ} 37^{\prime} 84^{\prime \prime}$ E.

\subsection{Experimental plant}

Mulberry (Morus spp) variety BM-11 (BM = Bangladesh Mulberry) and high-bush plantation system was used for this study. Mulberry plant (Morus sp) is small to medium sized shrubs or trees with a thick tan-gray ridged trunk which is perennial, deep rooted and hardy in nature. Due to its perennial, deep rooted and hardy habit, mulberry is grown in wide range of soil and agroclimatic conditions in Bangladesh.

\subsection{Experimental condition}

Generally, in Bangladesh silkworm is reared four commercially rearing seasons for each year. Depending upon the silkworm rearing season for this experiment the mulberry garden was pruned four times in a year each after three months interval. Two types of mulberry plant viz: (05) and (6-10) year's mulberry plants were used for this study. The phosphorus fertilizer treatments were applied 20 DAPr (Days after Pruning) when the sprouting of mulberry plant was started and other cultural practices like irrigation, digging cum weeding, insect-pest management practices etc. were done as per requirement.

\subsection{Experimental design and treatments}

This experiment was conducted in a randomized complete block (RCBD) design with three replications and the respective fertilizer treatments were randomly applied in the assign experimental plots. The following fertilizer treatments were applied in the experimental plots:

$\mathrm{T}_{0}$ : Only the BSRTI recommended basal dose of $\mathrm{N}$ and $\mathrm{K}$ were applied no $\mathrm{P}$ was applied (N $=300 \mathrm{~kg}$ and $\mathrm{K}=100 \mathrm{~kg} / \mathrm{ha} / \mathrm{yr}$ ).

$\mathrm{T}_{1}: \quad 40 \mathrm{~kg} \mathrm{P}+\mathrm{BSRTI}$ recommended basal dose of $\mathrm{N}$ and $\mathrm{K}$ per hectare per year.

$\mathrm{T}_{2}: \quad 80 \mathrm{~kg} \mathrm{P}+\mathrm{BSRTI}$ recommended basal dose of $\mathrm{N}$ and $\mathrm{K}$ per hectare per year.

$\mathrm{T}_{3}: \quad 120 \mathrm{~kg} \mathrm{P}+\mathrm{BSRTI}$ recommended basal dose of $\mathrm{N}$ and $\mathrm{K}$ per hectare per year.

$\mathrm{T}_{4}: \quad 160 \mathrm{~kg} \mathrm{P}+\mathrm{BSRTI}$ recommended basal dose of $\mathrm{N}$ and $\mathrm{K}$ per hectare per year. 
International Journal of Agriculture and Environmental Research

ISSN: 2455-6939

Volume: 06, Issue: 06 "November-December 2020"

$\mathrm{T}_{5}: \quad 200 \mathrm{~kg} \mathrm{P}+\mathrm{BSRTI}$ recommended basal dose of $\mathrm{N}$ and $\mathrm{K}$ per hectare per year.

\subsection{Recorded growth attributes}

Growth attributes namely, node per meter, length of longest shoot per plant, total branch number per plant, total branch height per plant $(\mathrm{cm})$, total shoot weight per plant $(\mathrm{g}), 10$ leaf area per plant $\left(\mathrm{cm}^{2}\right), 10$ leaf weight per plant (gm) and total leaf yield/ha/year (mt) were recorded crop wise. Data were collected at 90 DAPr for each cropping seasons. i.e. four times data was collected in a year and the annual yield was computed by pooling the two years data.

\subsection{Analysis of leaf quality parameters}

The mulberry leaf samples at different heights of the plant (top, middle and bottom) were collected in paper bags at $75 \mathrm{~d}$ after pruning and composite leaf samples were made. Then the leaves sample were shade dried for three days and again then dried in hot air oven at $700^{\circ} \mathrm{C}$ for one hour and were ground into powder for chemo-assay. The moisture (\%) was determined by followed the Vijayan et al. (1996), Chlorophyll-a and Chlorophyll-b content were estimated following the procedure outlined by Hiscox and Israelstam (1979) using the spectrophotometer and were computed using the standard formulae (Arnon 1949), total mineral (\%) followed the AOAC (1980), protein (\%) followed by the Kjeldahl's method (Wong 1923), total sugar and reducing sugar (\%) followed by the Miller (1972) and Loomis et al. (1937) procedure and methods and soluble carbohydrate (\%) followed by Dubois et al. (1956) method. Nitrogen, phosphorus and potassium contents in leaf were analyzed as per the standard procedures (Piper 1996) and ultimately the uptake of these nutrients was calculated.

\subsection{Measurement of soil physical and chemical properties}

The soil $\mathrm{pH}$ was determined in deionizer water using a soil: water ratio of 1:5 by using the glass electrode method (Haber et al. 1909). Soil organic C was determined by chromic acid digestion and spectrophotometric analysis (Heanes, 1984). Soil organic matter content was determined by multiplying the percent value of organic carbon with the conventional Van-Bemmelen's factor of 1.724 (Piper 1950). The nitrogen content of the soil sample was determined by distilling soil with alkaline potassium permanganate solution (Subhaiah and Asija 1956). The distillate was collected in $20 \mathrm{ml}$ of $2 \%$ boric acid solution with methylred and bromocresol green indicator and titrated with $0.02 \mathrm{~N}$ sulphuric acid $\left(\mathrm{H}_{2} \mathrm{SO}_{4}\right)$ (Podder et al. 2012). Soil available $\mathrm{S}$ (ppm) was determined by calcium phosphate extraction method with a spectrophotometer at $535 \mathrm{~nm}$ (Petersen 1996). The soil available $\mathrm{K}$ was extracted with $1 \mathrm{~N} \mathrm{NH}_{4} \mathrm{OAC}$ and determined by an atomic absorption spectrometer (Biswas et al. 2012). The available $\mathrm{P}$ of the soil was determined by spectrophotometer at a wavelength of $890 \mathrm{~nm}$. The soil sample was extracted by Olsen 
International Journal of Agriculture and Environmental Research

ISSN: 2455-6939

Volume: 06, Issue: 06 "November-December 2020"

method with $0.5 \mathrm{M} \mathrm{NaHCO}_{3}$ as outlined by Huq and Alam (2005). $\mathrm{Zn}$ in the soil sample was measured by an atomic absorption spectrophotometer (AAS) after extracting with DTPA Soltanpour and Workman (1979).

\subsection{Analysis of diseases data}

For a period of two consecutive years in each replication 10 mulberry plants were taken into observation to study the incidence of respective diseases and data were collected at 60 days after pruning. Disease incidence (\%) was assessed as number of total mulberry leaves per plant was infected by powdery mildew, leaf spot and leaf rust diseases with any visible symptom of respective disease. The percentage of disease incidence (PDI) was calculated using the formula of Rai and Mamatha (2005) which was following:

Percent Disease Incidence $(\mathrm{PDI})=\frac{\text { Numberoftotal leaves on each plant }}{\text { Numberof diseased leaves on each plant }} \times 100$

\subsection{Statistical Analysis}

The growth and yield contributing data were analyzed by using the Genstat $12.1^{\text {th }} \mathrm{ed}^{\mathrm{n}}$ for Windows (Lawes Agricultural Trust, UK) and one-way ANOVA was performed to detect differences for each parameter among the treatments. Sigma Plot 12.5 versions was used for representing the results as a figure form. The leaf quality, nutrient uptake and diseases data were statistically analyzed and mean values were evaluated by DMRT test through using the Statistic10 software. In case of soil the mean values of post harvest soil properties were recorded for this study.

\section{RESULTS}

\subsection{Effect of phosphorus on post harvest soil properties of mulberry garden}

The average physicochemical properties of the post harvest experimental soil are presented in table-1. The average post-harvest soil $\mathrm{pH}, \mathrm{OM}, \mathrm{N}, \mathrm{P}, \mathrm{K}, \mathrm{Zn}, \mathrm{Ca}$ and $\mathrm{Mg}$ for (0-5) year's plant were 7.4 to $8.1,1.21$ to $1.61 \%, 0.06$ to $0.9 \%, 10.3$ to $18.8 \mathrm{micro} \mathrm{g} / \mathrm{g}, 0.16$ to $0.19 \mathrm{meq} / 100 \mathrm{~g}$ soil, 0.54 to $0.66 \mathrm{micro} \mathrm{g} / \mathrm{g}, 17.35$ to $17.55 \mathrm{meq} / 100 \mathrm{~g}$ soil and 2.31 to $2.56 \mathrm{meq} / 100 \mathrm{~g}$ soil respectively. On the other hand, the average soil $\mathrm{pH}, \mathrm{OM}, \mathrm{N}, \mathrm{P}, \mathrm{K}, \mathrm{Zn}, \mathrm{Ca}$ and $\mathrm{Mg}$ for (6-10) year's plant were 7.3 to $8.2,1.23$ to $1.63 \%, 0.07$ to $0.09 \%, 10.3$ to 18.9 micro $\mathrm{g} / \mathrm{g}, 0.18$ to 0.20 meq/100 g soil, 0.55 to $0.66 \mathrm{micro} \mathrm{g} / \mathrm{g}, 17.33$ to $17.53 \mathrm{meq} / 100 \mathrm{~g}$ soil and 2.29 to $2.57 \mathrm{meq} / 100$ g soil respectively. 
International Journal of Agriculture and Environmental Research

ISSN: 2455-6939

Volume: 06, Issue: 06 "November-December 2020"

Table 1: Effect of different phosphorus levels on physicochemical properties of the post harvest soil

\begin{tabular}{|c|c|c|c|c|c|c|c|c|c|c|c|c|c|c|c|c|}
\hline \multirow[t]{3}{*}{ Treatments } & \multicolumn{2}{|c|}{ Soil pH } & \multicolumn{2}{|c|}{ OM (\%) } & \multirow{2}{*}{\multicolumn{2}{|c|}{$\mathbf{N}(\%)$}} & \multirow{2}{*}{\multicolumn{2}{|c|}{$\begin{array}{c}\text { P (micro } \\
\text { g/g) } \\
\text { Plant age }\end{array}$}} & \multirow{2}{*}{\multicolumn{2}{|c|}{$\begin{array}{c}\text { K (meq/100 } \\
\text { g soil) } \\
\text { Plant age }\end{array}$}} & \multirow{2}{*}{\multicolumn{2}{|c|}{$\begin{array}{c}\text { Zn (micro } \\
\text { g/g) } \\
\text { Plant age }\end{array}$}} & \multirow{2}{*}{\multicolumn{2}{|c|}{$\begin{array}{c}\text { Ca (meq/100 g } \\
\text { soil) } \\
\text { Plant age }\end{array}$}} & \multirow{2}{*}{\multicolumn{2}{|c|}{$\begin{array}{c}\text { Mg (meq } / 100 \\
\text { g soil) } \\
\text { Plant age }\end{array}$}} \\
\hline & Pla & age & Pla & age & & age & & & & & & & & & & \\
\hline & $\begin{array}{l}(0- \\
5)\end{array}$ & $\begin{array}{l}(6- \\
10)\end{array}$ & $\begin{array}{l}(0- \\
5)\end{array}$ & $\begin{array}{l}\text { (6- } \\
10)\end{array}$ & $\begin{array}{l}(0- \\
5)\end{array}$ & $\begin{array}{l}\text { (6- } \\
10)\end{array}$ & $\begin{array}{l}(0- \\
5)\end{array}$ & $\begin{array}{l}(6- \\
10)\end{array}$ & $\begin{array}{l}(0- \\
5)\end{array}$ & $\begin{array}{l}\text { (6- } \\
10)\end{array}$ & $\begin{array}{l}(0- \\
5)\end{array}$ & $\begin{array}{l}\text { (6- } \\
10)\end{array}$ & $(0-5)$ & $(6-10)$ & $\begin{array}{l}(0- \\
5)\end{array}$ & $\begin{array}{l}(6- \\
10)\end{array}$ \\
\hline $\mathrm{T}_{0}$ & 7.4 & 7.3 & 1.21 & 1.23 & 0.06 & 0.07 & 10.3 & 9.3 & 0.16 & 0.18 & 0.54 & 0.55 & 17.33 & 17.35 & 2.31 & 2.29 \\
\hline $\mathrm{T}_{1}$ & 7.4 & 7.4 & 1.25 & 1.27 & 0.07 & 0.07 & 13.7 & 13.9 & 0.17 & 0.18 & 0.56 & 0.57 & 17.41 & 17.43 & 2.35 & 2.37 \\
\hline $\mathrm{T}_{2}$ & 7.7 & 7.8 & 1.37 & 1.41 & 0.08 & 0.09 & 14.9 & 14.9 & 0.18 & 0.17 & 0.59 & 0.61 & 17.45 & 17.46 & 2.34 & 2.35 \\
\hline $\mathrm{T}_{3}$ & 7.9 & 7.9 & 1.42 & 1.44 & 0.08 & 0.09 & 18.4 & 18.5 & 0.19 & 0.18 & 0.63 & 0.65 & 17.47 & 17.45 & 2.47 & 2.47 \\
\hline $\mathrm{T}_{4}$ & 8.1 & 7.9 & 1.52 & 1.51 & 0.08 & 0.09 & 18.6 & 18.5 & 0.19 & 0.20 & 0.64 & 0.66 & 17.51 & 17.5 & 2.53 & 2.54 \\
\hline $\mathrm{T}_{5}$ & 8.1 & 8.2 & 1.61 & 1.63 & 0.09 & 0.09 & 18.8 & 18.9 & 0.19 & 0.20 & 0.66 & 0.65 & 17.53 & 17.55 & 2.56 & 2.57 \\
\hline
\end{tabular}

Where, $\mathrm{T}_{0}=0 \mathrm{~kg} \mathrm{P} / \mathrm{ha} / \mathrm{yr}, \mathrm{T}_{1}=40 \mathrm{~kg} \mathrm{P} / \mathrm{ha} / \mathrm{yr}, \mathrm{T}_{2}=80 \mathrm{~kg} \mathrm{P} / \mathrm{ha} / \mathrm{yr}, \mathrm{T}_{3}=120 \mathrm{~kg} \mathrm{P} / \mathrm{ha} / \mathrm{yr}, \mathrm{T}_{4}=160 \mathrm{~kg} \mathrm{P} / \mathrm{ha} / \mathrm{yr}$ and $\mathrm{T}_{5}=200 \mathrm{~kg} \mathrm{P} / \mathrm{ha} / \mathrm{yr}$.

\subsection{Growth response of mulberry plant due to ages of plant and Phosphorus}

\subsubsection{Node per meter per plant}

The average node per meter of mulberry plant was highly significant $(P<0.001)$ both for the plant ages and elevated $\mathrm{P}$ application. Among the six levels of $\mathrm{P}$ and two ages of mulberry plant the maximum average node/meter was 35.30 in the leaves of (6-10 year's plant) plant for the application of $160 \mathrm{~kg} \mathrm{P} / \mathrm{ha} / \mathrm{yr}$ with $300 \mathrm{~kg} \mathrm{~N}$ and $100 \mathrm{~kg} \mathrm{~K} / \mathrm{ha} / \mathrm{yr}\left(\mathrm{T}_{4}\right)$ in four split doses. Also the interactive effect between plant ages and fertilizer treatment was significantly $(P<0.01)$ differ (Table 2, Fig. 1). The minimum average node per meter was 21.63 in (0-5) year's plant for Control.

Table 2: Effect of different levels of Phosphorus on mulberry plant production

\begin{tabular}{ccccccccc}
\hline Factors & $\begin{array}{c}\text { Node/ } \\
\text { Meter }\end{array}$ & $\begin{array}{c}\text { Total } \\
\text { branch } \\
\text { number }\end{array}$ & $\begin{array}{c}\text { Length of } \\
\text { longest } \\
\text { shoot/plant }(\mathrm{cm})\end{array}$ & $\begin{array}{c}\text { Total branch } \\
\text { height/plant } \\
(\mathrm{cm})\end{array}$ & $\begin{array}{c}\text { Total shoot } \\
\text { weight/pant } \\
(\mathrm{g})\end{array}$ & $\begin{array}{c}\text { 10 Leaf } \\
\text { area/pla } \\
\mathrm{nt}\left(\mathrm{cm}^{2}\right)\end{array}$ & $\begin{array}{c}\text { 10 Leaf } \\
\text { weight/ } \\
\text { plant }(\mathrm{g})\end{array}$ & $\begin{array}{c}\text { Total Leaf } \\
\text { Yield/ha/yr } \\
(\mathrm{mt})\end{array}$ \\
\hline Age & $* * *$ & n.s & $*$ & $* * *$ & n.s & n.s & $* * *$ & $* * *$ \\
Treatments & $* * *$ & $* * *$ & $* * *$ & $* * *$ & $* * *$ & $* * *$ & $* * *$ & $* * *$ \\
Age $\times$ & $* *$ & $*$ & n.s & $* *$ & n.s & n.s & $*$ & n.s. \\
Treatment & & & & & & & & \\
\hline
\end{tabular}

Where, n.s., $* * *$ and $* * *$ represent not significant, probability of $>0.05, \leq 0.05, \leq 0.01$ and $\leq 0.001$. Values were means of three replicates. 


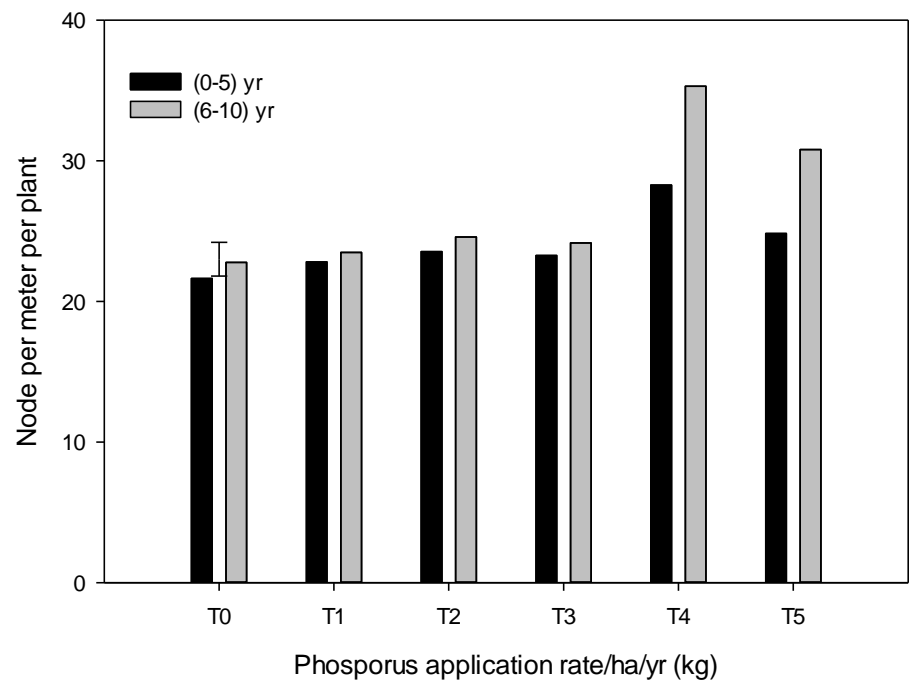

Fig. 1: Node per meter in mulberry plants as influenced by various levels of $P$ management practices. Where, $T_{0}=0 \mathrm{~kg} P / y e a r, T_{1}=40 \mathrm{~kg} P / y e a r, T_{2}=80 \mathrm{~kg} P / y e a r, T_{3}=120 \mathrm{~kg}$ $P / y e a r, T_{4}=160 \mathrm{~kg} P / y e a r$ and $T_{5}=200 \mathrm{~kg} P / y e a r$. Vertical bar represent $\mathrm{LSD}(P=0.05)$ different levels of phosphorus and mulberry plant age interactions.

\subsubsection{Length of longest shoot per plant $(\mathrm{cm})$}

The length of longest shoot of mulberry plant was significantly increased due to the ages of mulberry plant $(P<0.05)$ and the elevated doses of phosphorus $(P<0.001)$. But the interactive effect of plant age and $\mathrm{p}$ fertilizer treatment was not significantly differed for the length of longest shoot of the mulberry plant. However, the maximum average length of longest shoot was $165.13 \mathrm{~cm}$ in (6-10) year's mulberry plant for the treatment of $\mathrm{T}_{4}$, where as the minimum length of longest shoot was $122.50 \mathrm{~cm}$ in (0-5) year's plant for control treatment (Table 2, Fig. 2). 


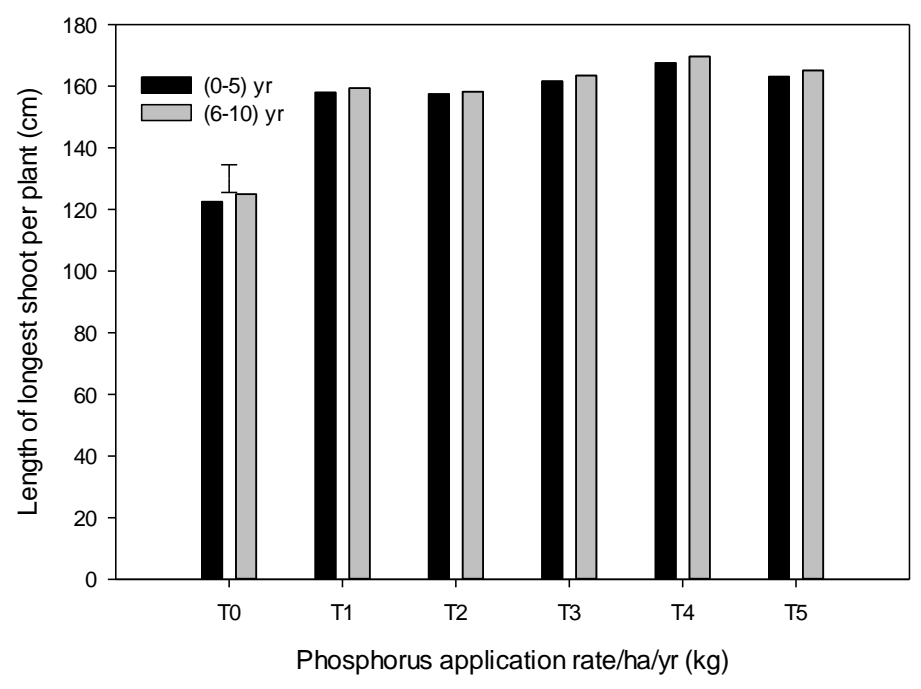

Fig. 2: Length of longest shoot per plant in mulberry plants as influenced by various levels of $P$ management practices. Where, $T_{0}=0 \mathrm{~kg} P / y e a r, T_{1}=40 \mathrm{~kg} P / y e a r, T_{2}=80 \mathrm{~kg} P / y e a r$, $T_{3}=120 \mathrm{~kg} P / y e a r, T_{4}=160 \mathrm{~kg} P / y e a r$ and $T_{5}=200 \mathrm{~kg} P / y e a r$. Vertical bar represent LSD $(P=0.05)$ different levels of phosphorus and mulberry plant age interactions.

\subsubsection{Total branch number per plant}

The total branch number per plant was highly significant $(P<0.001)$ due to the $\mathrm{P}$ treatment. But there were no significant differences between the two ages of mulberry plant. However, the average maximum total branch number/plant was 15.27 in older (6-10 years) plant for $\mathrm{T}_{4}(300$ Kg N/ha/yr + $160 \mathrm{Kg} \mathrm{P} / \mathrm{ha} / \mathrm{yr} /+100 \mathrm{~K} / \mathrm{ha} / \mathrm{yr}$ ) (Table 2, Fig. 3). 


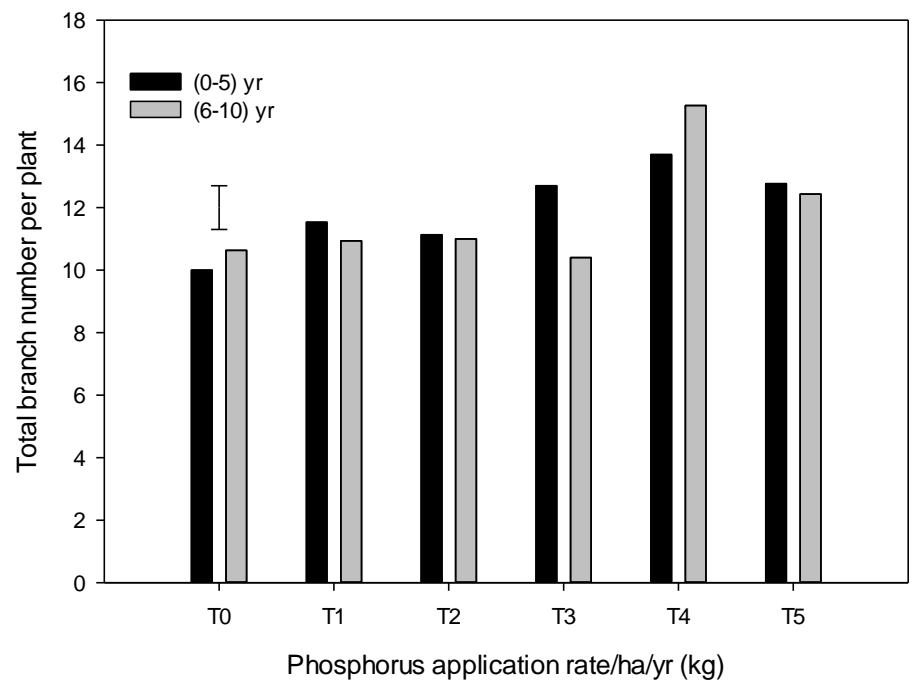

Fig. 3: Total branch number per plant in mulberry plants as influenced by various levels of $P$ management practices. Where, $T_{0}=0 \mathrm{~kg} P / y e a r, T_{1}=40 \mathrm{~kg} P / y e a r, T_{2}=80 \mathrm{~kg} P / y e a r, T_{3}$ $=120 \mathrm{~kg} P /$ year, $T_{4}=160 \mathrm{~kg} P /$ year and $T_{5}=200 \mathrm{~kg}$ P/year. Vertical bar represent LSD $(P=0.05)$ different levels of phosphorus and mulberry plant age interactions.

\subsubsection{Total branch height per plant $(\mathrm{cm})$}

The total branch height of mulberry plant was highly significant $(P<0.001)$ due to the ages of mulberry plant, phosphorus fertilizer treatment and also the interactive effect (plant age's $\times$ treatment). The maximum average total branch height per plant was $1145.67 \mathrm{~cm}$ in (6-10) year's plant for $\mathrm{T}_{4}$ treatment and the minimum height was $1078.72 \mathrm{~cm}$ in $(0-5)$ year's plant for the control treatment (Table 2, Fig. 4). 


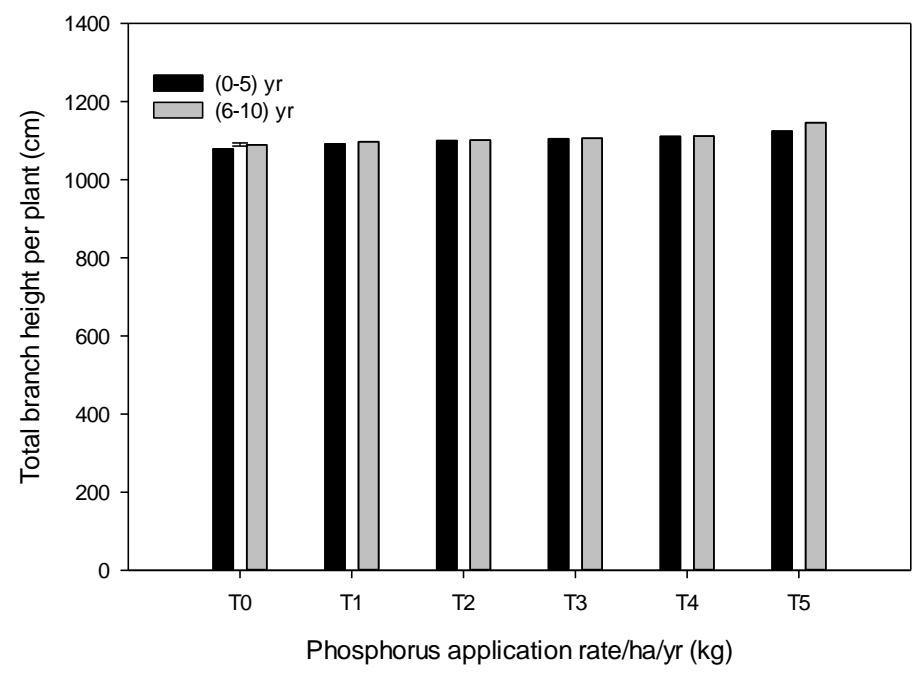

Fig. 4: Total branch height per plant in mulberry plants as influenced by various levels of $P$ management practices. Where, $T_{0}=0 \mathrm{~kg} P / y e a r, T_{1}=40 \mathrm{~kg} P / y e a r, T_{2}=80 \mathrm{~kg} P / y e a r, T_{3}=$ $120 \mathrm{~kg}$ P/year, $\mathrm{T}_{4}=160 \mathrm{~kg} P /$ year and $\mathrm{T}_{5}=200 \mathrm{~kg}$ P/year. Vertical bar represent $\mathrm{LSD}(P=$ 0.05) different levels of phosphorus and mulberry plant age interactions.

\subsubsection{Total shoot weight per plant (g)}

The total shoot weight of mulberry plant was significantly $(P<0.001)$ increased due to the application of different levels of phosphorus fertilizer. The maximum average total shoot weight was $827.55 \mathrm{~g}$ in (6-10) year's mulberry plant for the treatment of $\mathrm{T}_{4}$ whereas, the minimum total shoots weight was $755.29 \mathrm{~g}$ for control treatment (Table 2, Fig. 5). 


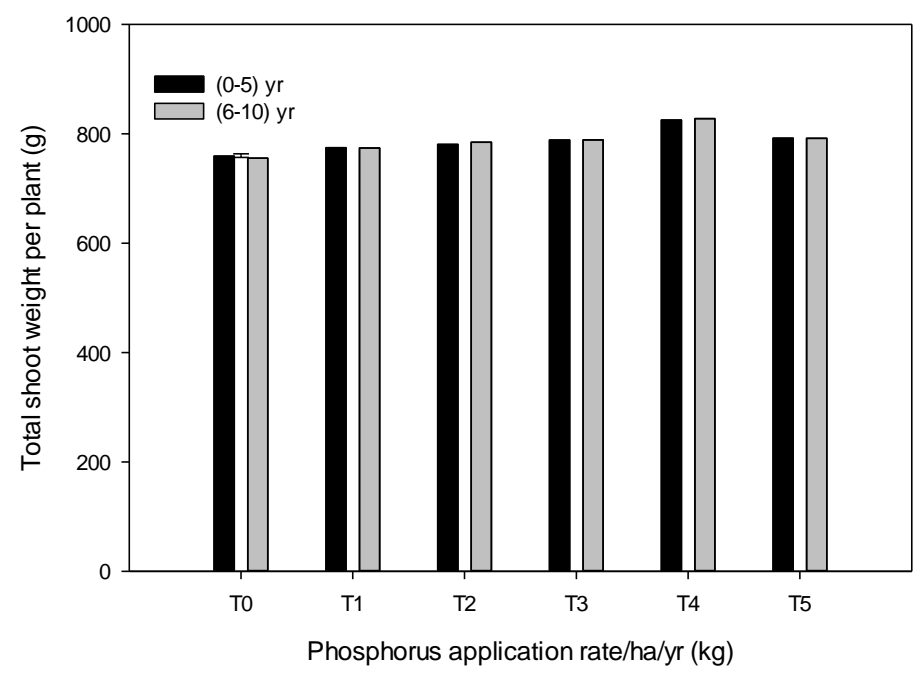

Fig. 5: Total shoot weight per plant in mulberry plants as influenced by various levels of $P$ management practices. Where, $T_{0}=0 \mathrm{~kg} P /$ year, $T_{1}=40 \mathrm{~kg} P / y e a r, T_{2}=80 \mathrm{~kg} P / y e a r, T_{3}=$ $120 \mathrm{~kg}$ P/year, $\mathrm{T}_{4}=160 \mathrm{~kg} P /$ year and $\mathrm{T}_{5}=200 \mathrm{~kg}$ P/year. Vertical bar represent $\mathrm{LSD}(P=$ 0.05) different levels of phosphorus and mulberry plant age interactions.

\subsubsection{0 leaf area/plant $\left(\mathrm{cm}^{2}\right)$}

The maximum average 10 leaf areas per plant was $674.89 \mathrm{~cm}^{2}$ in $(6-10)$ year's plant for $\mathrm{T}_{4}(300$ $\mathrm{Kg} \mathrm{N} / \mathrm{ha} / \mathrm{yr}+160 \mathrm{Kg} \mathrm{P} / \mathrm{ha} / \mathrm{yr} / 100 \mathrm{~K} / \mathrm{ha} / \mathrm{yr}$ ) treatment which was significantly differ only for the $\mathrm{P}$ levels. But the average 10 leaf area was non significant due to the plant ages and the interactive effect between plant ages and $\mathrm{P}$ treatment. However, the minimum 10 leaf area was $476.98 \mathrm{~cm}^{2}$ in (0-5) year plant for Control (Table 2, Fig. 6). 


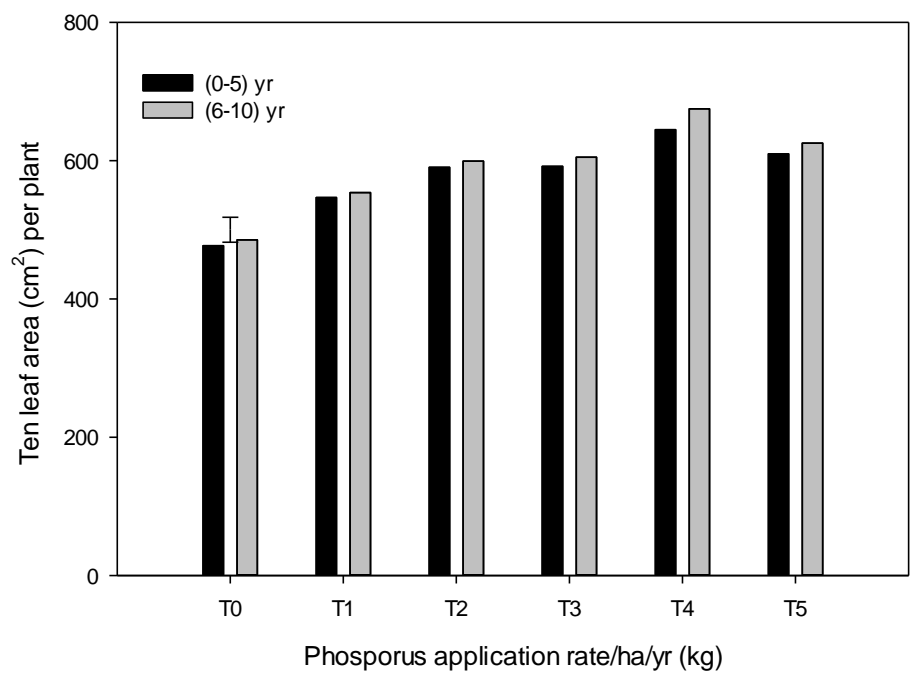

Fig. 6: 10 leaf area/plant in mulberry plants as influenced by various levels of $P$ management practices. Where, $T_{0}=0 \mathrm{~kg} P /$ year, $T_{1}=40 \mathrm{~kg} P / y e a r, T_{2}=80 \mathrm{~kg} P / y e a r, T_{3}=$ $120 \mathrm{~kg}$ P/year, $T_{4}=160 \mathrm{~kg} P /$ year and $T_{5}=200 \mathrm{~kg} P /$ year. Vertical bar represent $\mathrm{LSD}(P=$ 0.05) different levels of phosphorus and mulberry plant age interactions.

\subsubsection{0 leaf weight per plant (gm)}

The differences in the average ten leaf weight per plant were highly significant $(P<0.001)$ both for the plant ages and the $\mathrm{P}$ levels. Among the six $\mathrm{P}$ levels the maximum average 10 leaf weight was $46.67 \mathrm{gm}$ in (6-10) year's plant for the application of $160 \mathrm{~kg} \mathrm{P} / \mathrm{ha} / \mathrm{yr}$ with $300 \mathrm{~kg} \mathrm{~N}$ and 100 $\mathrm{kg} \mathrm{K} / \mathrm{ha} / \mathrm{yr}$ in four split doses. Even the interactive effect between mulberry plant age and $\mathrm{P}$ treatment was significantly differed. However, the minimum 10 leaf weight was $35.33 \mathrm{gm}$ in (05) year's plant for control (Table 2, Fig. 7). 


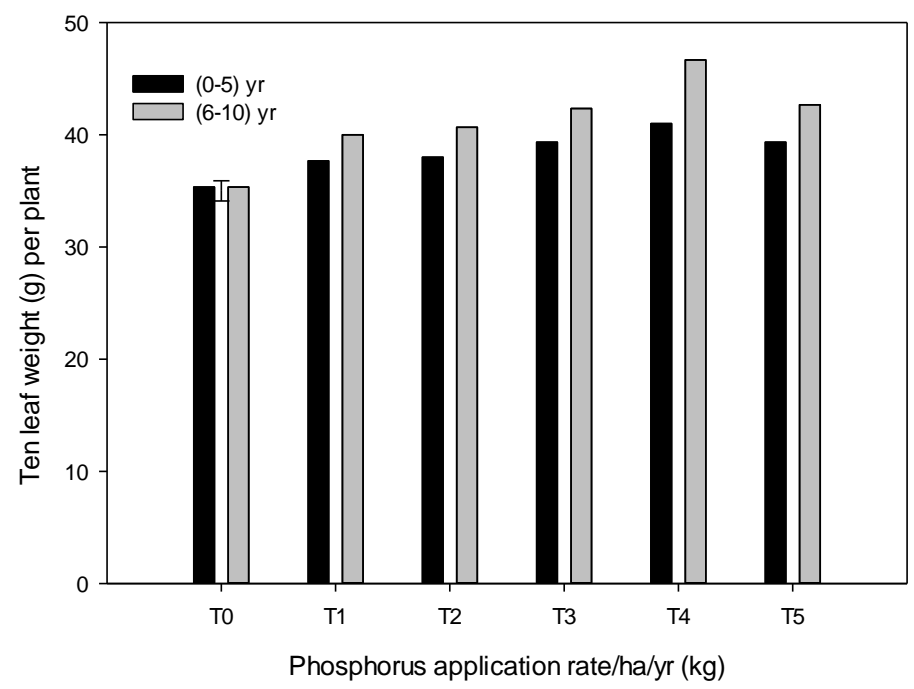

Fig. 7: Ten leaf weight per plant in mulberry plants as influenced by various levels of $P$ management practices. Where, $T_{0}=0 \mathrm{~kg} P / y e a r, T_{1}=40 \mathrm{~kg} P / y e a r, T_{2}=80 \mathrm{~kg} P / y e a r, T_{3}=$ $120 \mathrm{~kg} P /$ year, $T_{4}=160 \mathrm{~kg} P /$ year and $T_{5}=200 \mathrm{~kg} P /$ year. Vertical bar represent $\mathrm{LSD}(P=$ 0.05) different levels of phosphorus and mulberry plant age interactions.

\subsubsection{Total leaf yield/ha/year (MT)}

The average total leaf yield/ha/year was highly significant $(P<0.001)$ for mulberry plant ages, $\mathrm{P}$ levels and the interactive effect between plant ages and $\mathrm{P}$ treatment respectively. The highest total leaf yield per hectare per year was 47.69 metric ton in (6-10) year's plant due to the application of $160 \mathrm{~kg} \mathrm{P} / \mathrm{ha} / \mathrm{yr}$ with $300 \mathrm{~kg} \mathrm{~N}$ and $100 \mathrm{~kg} \mathrm{~K} / \mathrm{ha} / \mathrm{yr}$ in four split doses. However, the minimum leaf yield per hectare per year was 27.78 metric ton in (0-5) year's plant for control (Table 2, Fig. 8). 


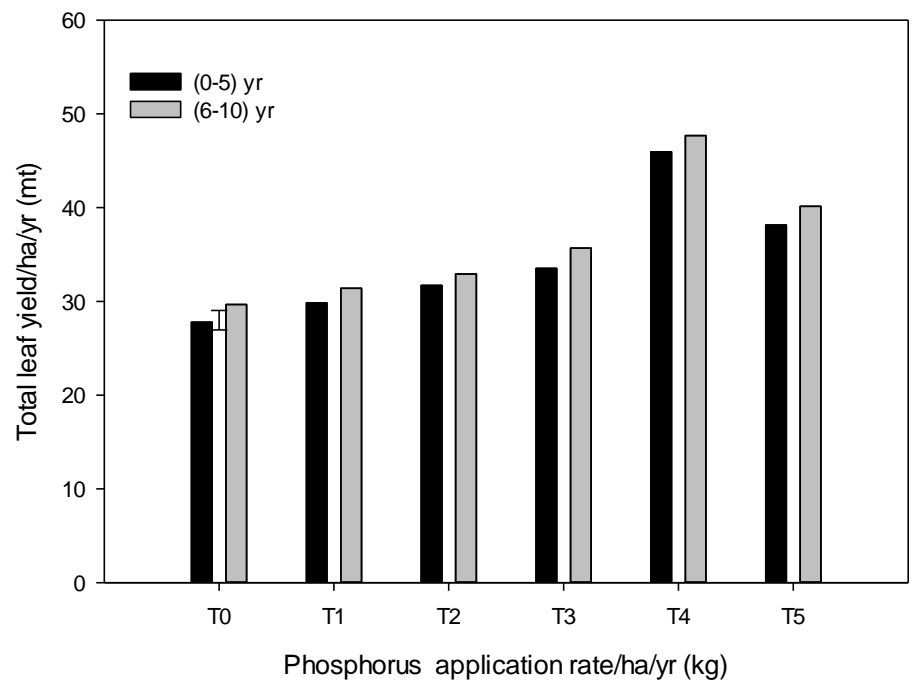

Fig. 8: Total leaf yield/ha/year in mulberry plants as influenced by various levels of $P$ management practices. Where, $T_{0}=0 \mathrm{~kg} P / y e a r, T_{1}=40 \mathrm{~kg} P / y e a r, T_{2}=80 \mathrm{~kg} P / y e a r, T_{3}=$ $120 \mathrm{~kg}$ P/year, $T_{4}=160 \mathrm{~kg} P /$ year and $T_{5}=200 \mathrm{~kg}$ P/year. Vertical bar represent $\mathrm{LSD}(P=$ 0.05) different levels of phosphorus and mulberry plant age interactions.

\subsection{Effect of ages of mulberry plant and phosphorus on leaf quality of mulberry}

\subsubsection{Moisture (\%)}

The moisture (\%) of mulberry leaf was significantly increased due to the plant ages and P levels. Among the six fertilizer treatments the maximum moisture (\%) 74.59 was recorded in the leaf of (6-10) year's plant for the treatment of $\mathrm{T}_{4}(300 \mathrm{~kg} \mathrm{~N} / \mathrm{ha} / \mathrm{yr}+160 \mathrm{~kg} \mathrm{P} / \mathrm{ha} / \mathrm{yr}+100 \mathrm{~kg} \mathrm{~K} / \mathrm{ha} / \mathrm{yr})$ which was statistically similar with the treatment of $\mathrm{T}_{2}$. The minimum moisture (\%) 65.93 was recorded in the leaf of (0-5) years mulberry plant for control (Table 3 ).

\subsubsection{Chlorophyll-a (micro g/g)}

The Chlorophyll-a content in mulberry leaf was not statistically improved due to the plant ages and $\mathrm{P}$ treatment. However, the maximum Chlorophyll-a 2.46 micro g was recorded in the leaf of (6-10) year's plant for the treatment of $\mathrm{T}_{5}$ and the minimum Chlorophyll-a was 1.74 micro $\mathrm{g}$ for $\mathrm{T}_{1}$ and $\mathrm{T}_{3}$ (Table 3 ).

\subsubsection{Chlorophyll-b (micro g/g)}


The plant ages and $\mathrm{P}$ levels did not significantly change the Chlorophyll-b content in mulberry leaf. However, the maximum Chlorophyll-b was 59.95 micro g in (6-10) year's mulberry plant for the treatment of $\mathrm{T}_{5}$ and the minimum Chlorophyll-b was 48.36 micro $g$ in (0-5) year's plant for control (Table 3).

\subsubsection{Total Mineral (\%)}

The total mineral content in mulberry leaves was significantly improved due to the plant ages and P levels. The maximum total mineral was found $10.07 \%$ in the leaves of (6-10) year's plant for $\mathrm{T}_{4}$ treatment which was statistically similar with $\mathrm{T}_{3}$. However, the minimum total mineral was $8.23 \%$ in the leaves of (0-5) year's plant for control (Table 3).

\subsubsection{Crude Protein (\%)}

The ages of mulberry plant and level of $\mathrm{P}$ fertilizer significantly increased the crude protein content in mulberry leaf. Among the two ages of mulberry plant the maximum crude protein was $21.86 \%$ in (6-10) year's plant for the $\mathrm{T}_{4}$ treated mulberry plant. However, the minimum crude protein was $14.18 \%$ in (0-5) year's plant for control (Table 3).

\subsubsection{Soluble Carbohydrate (\%)}

The soluble carbohydrate content in mulberry was significantly changed due to the plant ages and application of different level of P. Between the (0-5) and (6-10) year's mulberry plant the maximum soluble carbohydrate was $9.77 \%$ in (6-10) year's plant for $\mathrm{T}_{4}$ treated plant. However, the minimum soluble carbohydrate was $6.65 \%$ in the leaves of $(0-5)$ year's plant for control (Table 3).

\subsubsection{Total Sugar (\%)}

The ages of mulberry plant and levels of $\mathrm{P}$ significantly improved the total sugar content in mulberry leaves. Among the six levels of $\mathrm{P}$ the maximum total sugar was $6.10 \%$ in the leaves of (6-10) year's plant for $\mathrm{T}_{4}$ treated mulberry plant. Conversely, the minimum total sugar was 4.48 $\%$ in $(0-5)$ year plant for control (Table 3$)$.

\subsubsection{Reducing Sugar (\%)}

The reducing sugar $(\%)$ in mulberry leaves was significantly increased due to the ages of mulberry plant and levels of $\mathrm{P}$ fertilizer. Among the two ages of mulberry plant the maximum reducing sugar was $3.78 \%$ in the leaves of (6-10) year's plant for $\mathrm{T}_{4}$ treated plant. However, the minimum reducing sugar was $3.03 \%$ in (0-5) year's plant for control (Table 3$)$. 
International Journal of Agriculture and Environmental Research

ISSN: 2455-6939

Volume: 06, Issue: 06 "November-December 2020"

\subsection{Effect of phosphorus on nutrients uptake by mulberry plant}

Nitrogen, phosphorus and potassium uptake by the mulberry leaves was significantly increased due to the mulberry plant ages and gradated doses of phosphorus. Among the six levels of phosphorus the maximum nitrogen, phosphorus and potassium uptake were 143.21, 24.44 and $64.72 \mathrm{~kg} / \mathrm{ha} / \mathrm{yr}$ respectively in (6-10) year's plant for the application of $160 \mathrm{~kg} \mathrm{P} / \mathrm{ha} / \mathrm{yr}$ with BSRTI recommended basal dose of $\mathrm{N}$ and $\mathrm{K}$ (Table 4).

\subsection{Effect of elevated phosphorus on common diseases infestation in mulberry plant}

The common infestation of powdery mildew, leaf spot and leaf rust diseases in (6-10) year's mulberry plant were drastically reduced due to the elevated $\mathrm{P}$ application in soil. The average powdery mildew, leaf spot and leaf rust incidence percentage were comparatively in the high level of $\mathrm{P}$ application. In case of powdery mildew and leaf spot diseases the average lower incidence percentages were 1.27 and 0.58 respectively for the treatment of $\mathrm{T}_{4}(120 \mathrm{~kg} \mathrm{P} / \mathrm{ha} / \mathrm{yr})$. But the lower average incidence percentage of leaf rust was 0.96 for the application of $90 \mathrm{~kg}$ $\mathrm{P} / \mathrm{ha} / \mathrm{yr}$ with four split doses of BSRTI recommended basal dose of $\mathrm{N}$ and $\mathrm{K}$. However, the average incidences percentages of all the three diseases were comparatively maximum for the control treatment than the others treatments (Table 5).

\section{DISCUSSION}

\subsection{Effect of phosphorus on mulberry leaf yield and quality}

Elevated doses of $\mathrm{P}$ considerably increased the leaf yield and quality of mulberry plant. Six levels of P viz: $0 \mathrm{~kg} \mathrm{P}, 40 \mathrm{~kg} \mathrm{P}, 80 \mathrm{~kg} \mathrm{P}, 120 \mathrm{~kg} \mathrm{P}, 160 \mathrm{~kg} \mathrm{P}$ and $200 \mathrm{~kg} \mathrm{P} / \mathrm{ha} / \mathrm{yr}$ respectively were applied with BSRTI recommended N and K@300 kg N and $100 \mathrm{~kg} \mathrm{~K} / \mathrm{ha} / \mathrm{yr}$ in four splits doses for mulberry plant production. The growth and yield contributing components of mulberry plant such as nodes per meter, total branch number, length of longest shoot, total shoot weight, total branches height, 10-leaf area, 10-leaf weight per plant and total leaf yield/ha/year were significantly $(P \leq 0.001)$ increased due to the application of $160 \mathrm{Kg} \mathrm{P} / \mathrm{ha} / \mathrm{yr}$ with $300 \mathrm{Kg} \mathrm{N} / \mathrm{ha} / \mathrm{yr}$ and $100 \mathrm{~K} / \mathrm{ha} / \mathrm{yr}$ as compared to the other treatments (Table 2). The maximum leaf yield was $47.69 \mathrm{mt} / \mathrm{ha} /$ year for the treatment of $\mathrm{T}_{4}(300 \mathrm{~kg} \mathrm{~N} / \mathrm{ha} / \mathrm{yr}+160 \mathrm{~kg} \mathrm{P} / \mathrm{ha} / \mathrm{yr}+100 \mathrm{~kg} \mathrm{~K} / \mathrm{ha} / \mathrm{yr})$ which was $60.79 \%$ higher than the maximum average yield of control treatment. The interactive effect of plant age $\times \mathrm{P}$ treatments the growth and yield contributing characters except length of longest shoot, total shoot weight, 10 leaf area $\left(\mathrm{cm}^{2}\right)$ per plant and total leaf yield/ha/year were also significantly differed (Table 2). Likewise, the nutritional components viz: moisture (\%), crude protein $(\%)$, total sugar $(\%)$, soluble carbohydrate $(\%)$ and reducing sugar $(\%)$ except chlorophyll-a, chlorophyll-b and total mineral $(\%)$ were also significantly improved for $\mathrm{T}_{4}(300$ 
International Journal of Agriculture and Environmental Research

ISSN: 2455-6939

Volume: 06, Issue: 06 "November-December 2020"

$\mathrm{kg} \mathrm{N} / \mathrm{ha} / \mathrm{yr}+160 \mathrm{~kg} \mathrm{P} / \mathrm{ha} / \mathrm{yr}+100 \mathrm{~kg} \mathrm{~K} / \mathrm{ha} / \mathrm{yr}$ ) treated mulberry plant. Our findings are more or less similar with the previous findings of Paul et al. (2009). They were applied four levels of $\mathrm{P}$ in four split doses viz; $0 \mathrm{~kg}, 100 \mathrm{~kg}, 150 \mathrm{~kg}$ and $200 \mathrm{~kg} \mathrm{P} / \mathrm{ha} / \mathrm{yr}$ with $\mathrm{N}$ and $\mathrm{K}$. Among the four levels of $\mathrm{P}$ the maximum values both for the yield components (plant height, number of branches per plant, number of leaves per branches and leaf yield per plant) and leaf quality parameters viz: leaves moisture, crude protein, reducing sugar, total sugar, starch and soluble carbohydrate except mineral were found for the application of $200 \mathrm{~kg} \mathrm{P} / \mathrm{ha} / \mathrm{yr}$ with $300 \mathrm{~kg} \mathrm{~N}$ and $100 \mathrm{~kg}$ $\mathrm{K} / \mathrm{ha} / \mathrm{yr}$. Similarly, Bose et al. (2009) found the significant impact of elevated $\mathrm{P}$ on mulberry leaf yield and quality. They were applied five levels of $\mathrm{P}_{2} \mathrm{O}_{5}$ as a basal @ 0, 15, 30, 45 and 60 $\mathrm{kg} / \mathrm{ha} / \mathrm{yr}$ and found that the plant height, leaf area and leaf yield with moisture contents were significantly increased due to $\mathrm{P}$ application from $30 \mathrm{~kg}$ to $60 \mathrm{~kg} \mathrm{P}_{2} \mathrm{O}_{5} / \mathrm{ha} / \mathrm{yr}$ over the control, the maximum being with $60 \mathrm{P}_{2} \mathrm{O}_{5} / \mathrm{ha} / \mathrm{yr}$. Likewise, Singh et al. (2016) reported that next to nitrogen, phosphorus is very important essential nutrients for plant growth and is found in every living plant cell which involved in several key plant functions, including energy transfer, photosynthesis rate, transformation of sugars and starches, nutrient movement within the plant and others related parameters that positively enhance the growth, leaf yield and quality of mulberry plant.

\subsection{Impact of mulberry plant ages on leaf yield and quality}

The leaf yield and quality of mulberry plant was significantly increased by the ages of plant. In our study the (6-10) year's mulberry plant was gave the maximum leaf yield with superior leaf quality than the (0-5) year's plant. We applied $0 \mathrm{~kg} \mathrm{P}, 40 \mathrm{~kg} \mathrm{P}, 80 \mathrm{~kg} \mathrm{P}, 120 \mathrm{~kg} \mathrm{P}, 160 \mathrm{~kg} \mathrm{P}$ and $200 \mathrm{~kg}$ P/ha/yr respectively with BSRTI recommended N and K @ $300 \mathrm{~kg} \mathrm{~N}$ and $100 \mathrm{~kg} \mathrm{K/ha/yr}$ in four splits doses for mulberry plant production. Between the (0-5) and (6-10) year's mulberry plant the maximum average growth and yield contributing parameters viz: nodes per meter per plant, length of longest shoot per plant, total branches height per plant, 10-leaf weight per plant and total leaf yield/ha/year were found for (6-10) year's mulberry plant than the (0-5) year's plant. However, the maximum average mulberry leaf yield was $47.69 \mathrm{mt} / \mathrm{ha} / \mathrm{year}$ which was $3.79 \%$ greater than the maximum average yield $45.95 \mathrm{mt}$ of (0-5) year's plant. Most of the leaves quality parameters except percentage mineral were also significantly increased due to the ages of mulberry plant whereas the maximum average moisture, Chlorophyll-a, Chlorophyll-b, crude protein, soluble carbohydrate, total sugar and reducing sugar were 74.59, 2.46, 55.95, 21.86, $9.77,6.10$ and $3.78(\%)$ respectively in (6-10) year's mulberry plant. In case of (0-5) year's plant the maximum average moisture, Chlorophyll-a, Chlorophyll-b, crude protein, soluble carbohydrate, total sugar and reducing sugar percentage were 73.90, 2.43, 52.09, 21.63, 9.59, 6.08 and $3.72(\%)$ respectively. This type of study was not conducted previously in mulberry crop. But, Deborah et al. (1990) found that the $\mathrm{P}$ absorption is increased by the older marigold 
International Journal of Agriculture and Environmental Research

ISSN: 2455-6939

Volume: 06, Issue: 06 "November-December 2020"

seedlings than the younger the seedlings. They found that the marigold (Tagetes erecta Big. Inca Gold) seedlings of 30, 35, 40, 45 and 50 days old $\mathrm{P}$ absorption rate was $0.38,0.41,0.92,1.70$ and $2.30 \mathrm{mg}$ respectively. This result implies that the $\mathrm{P}$ absorption by the older seedlings was higher than the younger seedlings of marigold which is more or less similar with our findings. However, they did not explain the causes of high $\mathrm{P}$ absorption by the older plant. But our speculation is due to the increased nutrient demand and absorption of (6-10) years plants compared to (0-5) years plants, regardless of $\mathrm{P}$ level, may be attributed to the well developed larger root system of the older mulberry plant accessing a greater volume of the soil which is corroborates with the findings of Radha et al. (1988). They reported that deficiency of phosphorus in nutrient solution reduced shoot length, root length, shoot weight, root weight and ultimately reduced the total leaf yield, confirming the importance of phosphorus.

\subsection{Phosphorus enhances the nutrient uptake by the mulberry plant}

Nitrogen phosphorus and potassium uptake in mulberry leaf were found significant in (6-10) year's plant for the application of $160 \mathrm{~kg} \mathrm{P} / \mathrm{ha} / \mathrm{yr}$ with BSRTI recommended basal dose of $\mathrm{N}$ and $\mathrm{K}$ which was corroborated with the findings of Bose et al. (2009). They were applied 0, 15, 30, 45 and $60 \mathrm{~kg} \mathrm{P} / \mathrm{ha} / \mathrm{yr}$ with $150 \mathrm{~kg} \mathrm{~N}$ and $50 \mathrm{~kg} \mathrm{~K} / \mathrm{ha} / \mathrm{yr}$ respectively and found that the nitrogen, phosphorus and potassium uptake were found to be statistically significant up to $60 \mathrm{~kg} \mathrm{P} / \mathrm{ha} / \mathrm{yr}$ which were $114.70,12.48$ and $54.67 \mathrm{~kg} / \mathrm{ha} / \mathrm{yr}$ respectively may be due to the synergistic interaction effect of higher dose of phosphorus. Our speculation was the higher levels of phosphorus (160 kg P/ha/yr) was comparatively optimum and available which influenced the $\mathrm{N}$, $\mathrm{P}$ and K uptake by the mulberry which is lined with the speculation of Prasad et al. (1992). They reported that application of phosphate significantly influenced the $\mathrm{N}$ and $\mathrm{P}$ uptake of mulberry.

\subsection{Effect of elevated phosphorus on mulberry diseases infestation}

Elevated phosphorus with BSRTI recommended basal doses of $\mathrm{N}$ and $\mathrm{P}$ suppress the incidences of powdery mildew, leaf spot and leaf rust diseases. Among the six levels of phosphorus the minimum powdery mildew and leaf spot infestation were $1.27 \%$ and $0.58 \%$ respectively for the application of $120 \mathrm{~kg} \mathrm{~K}$ with $300 \mathrm{~kg} \mathrm{~N}$ and $100 \mathrm{~kg} \mathrm{~K} / \mathrm{ha} / \mathrm{yr}$ for four split doses. But in case of leaf rust the lower incidence percentage was $0.96 \%$ for the treated of $90 \mathrm{~kg} P$ with $300 \mathrm{~kg} \mathrm{~N}$ and $100 \mathrm{~kg} \mathrm{~K} / \mathrm{ha} / \mathrm{yr}$ in four split doses. However, no study is available that elevated phosphorus reduces the foliar disease of mulberry plant. But, a study was conducted by Nwogbaga et al. (2015) who found that the downy mildew and other fungal diseases of Cucumber (Cucumis sativus L.) were significantly reduces due to the foliar application of NPK at the rate of 19.181 $\mathrm{kg} / \mathrm{ha}$. Similarly, Huber et al. (1999) found that $\mathrm{P}$ is most effective when it is applied to control the fungal disease of seedlings due to the faster root development allows to the plant to escape 
disease. Our speculation is that $\mathrm{P}$ is the essential element of the building blocks of life, the ribonucleic acids (RNA), as well as being required for many additional biochemical and physiological processes including energy transfer, protein metabolism, and other functions which may builds the defense mechanism against the fungal diseases of mulberry plant, as result the infestation of powdery mildew, leaf spot and leaf rust were comparatively low.

\section{CONCLUSION}

This study demonstrated that the application of elevated phosphorus in soil with BSRTI recommended basal dose of $\mathrm{N}$ and $\mathrm{K}$ is a progressive fertilizer management approach for mulberry cultivation. The elevated phosphorus application in soil enhances mulberry plant growth, leaf yield, mulberry leaf quality and suppresses common diseases of mulberry plant. Out of the six levels of phosphorus the application of $160 \mathrm{~kg}$ P with BSRTI recommended basal dose of $300 \mathrm{~kg} \mathrm{~N}$ and $100 \mathrm{~kg} \mathrm{~K}$ per/ha/yr through four split doses gave the best performances among all the treatments. Therefore, this study concluded that $160 \mathrm{~kg} \mathrm{P}$ per hectare per year in combination with BSRTI recommended basal dose of nitrogen and potassium can be recommended to the sericulture farmers to obtain a higher leaf yield with superior nutritive value by suppress common diseases viz: powdery mildew, leaf spot and leaf rust of mulberry plant.

\section{ACKNOWLEDGEMENT}

The authors are grateful to the Soil Resource Development Institute (SRDI), Rajshahi, Bangladesh for providing analytical facilities for soil analysis. The authors are also obliged to the Bangladesh Council of Scientific \& Industrial Research (BCSIR), Rajshahi, Bangladesh for providing laboratory facilities for leaf quality analysis. The authors are thankful to the technical staff of Bangladesh Sericulture Research and Training Institute (BSRTI), Rajshahi for their assist towards experimentation. Finally, the author would like to thank the Bangladesh government for supporting the PhD study and Bangladesh Agricultural Research Council (BARC) for awarding the NATP-2 (National Agricultural Technology Program-Phase-II Project) Research Fellowship Grant to the Mr Faruque Ahmed.

\section{REFERENCES}

Arnon D I. 1949. Plant physiology.

Biswas A, Alamgir M, Haque S M S, Osman K T. 2012. Study on soils under shifting cultivation and other land use categories in Chittagong Hill Tracts. Bangladesh Journal of Forestry Research, 23(2), 261-265. 
International Journal of Agriculture and Environmental Research

ISSN: 2455-6939

Volume: 06, Issue: 06 "November-December 2020"

Bose P C, Srivastavad P, Kar R, Bajpai A K. 2009. Effect of phosphorus on growth, yield and nutrient uptake of rainfed mulberry (Morus alba 1.) and its economics in Chotanagpur Plateau of Jharkhand. Journal of Crop and Weed, 5(1), 23-26.

Deborah A, Tolmanl, Alexander X, Niemiera, Robert, D, Wright. 1990. Influence of plant age on nutrient absorption for marigold seedlings. Horticultural Science, 25(12), 1612-1613.

Dubios M, Giles K A, Hamilton T K, Robeos R A, Smith R. 1956. Calorimetric determination of sugars and Related Substances. Analytical Chemistry, 28, 250-256.

Guttierrez W A, Shew H D, Melton T A. 1997. Source of inoculums and management of rhizoctonia solani causing damping off on tobacco transplants under greenhouse conditions. Plant Disease, 81, 604-608.

Gallegos-Cedillo V M, Urrestarazu M, Álvaro J E. 2016. Influence of salinity on transport of nitrates and potassium by means of the xylem sap content between roots and shoots in young tomato plants. Journal of Soil Science and Plant Nutrition, 16(4), 991-998.

Haber F, Klemensiewicz Z. 1909. The results of their research on the glass electrode in the society of chemistry in Karlsruhe. The Journal of Physical Chemistry.

Heanes D L. 1984. Determination of organic C in soils by an improved chromic acid digestion and spectrophotometric procedure, comm. Soil Science and Plant Analysis, 15, 11911213.

Hiscox J D, Israelstam G F. 1979. Different methods of chlorophyll extraction. Canadian Journal of Botany, 57, 1332-1332.

Huq I M S, Alam M D. 2005. A handbook on analyses of soil, plant and water. Bacer-Du, University of Dhaka, Bangladesh. pp. 13-40.

Huber D M, Graham R D. 1999. The role of nutrition in crop resistance and tolerance to disease; In: Rengelz (ed) mineral nutrition of crops fundamental mechanisms and implications. Food Product Press, New York, pp. 205-226.

Jian Q I N, Ningjia H E, Yong W A N G, Zhonghuai X I A N G. 2012. Ecological issues of mulberry and sustainable development. Journal of Resources and Ecology, 4 (3), 330339. 
International Journal of Agriculture and Environmental Research

ISSN: 2455-6939

Volume: 06, Issue: 06 "November-December 2020"

Kashiviswanathan K, Sitaram Iyengar M N. 1966. Effect of NPK manuring on the seasonal and total yield of mulberry. Indian Journal of Sericulture, 6, 46-49.

Katan J. 2009. Mineral nutrient management and plant disease. In: research findings: e-ifc No. 21. International potash Institute.

Loomis E W, Shull A C. 1937. Methods in plant physiology. Mcgraw-Hill Book Company, New York.

Miller L G. 1972. Use of dinitrosalicylic acid reagent for determination of reducing sugar. Analytical Chemistry, 426-428.

Nwogbaga A C, Iwuagwu C C. (2015). Effect of fungicide and NPK foliar fertilizer application for the management of fungal diseases of cucumber (Cucumis sativus L.). Scholars Journal of Agriculture and Veterinary Sciences, 2(3A), 182-186.

Paul N K, Qaiyyum M A. 2009. Effect of different levels of npk fertilizer sand irrigation on yield and nutritive quality of mulberry leaf. Bangladesh Journal of Agricultural Research, 34 (3), 435-442.

Petersen L. 1996. Soil analytical methods soil testing management and development. Soil Resources Development Institute, Dhaka, Bangladesh. Pp. 1-28.

Piper C S. 1950. Soil and plant analysis. Adelaide University. Hassel Press, Australia.368p.

Piper C S. 1996. Soil and plant analysis, Hans Publishers, Bombay.

Podder M, Akter M, Saifullah M S A, Roy S. 2012. Impacts of plough pan on physical and chemical properties of soil. Journal of Environmental Science \& Natural Resources, 5(1), 289-294.

Prasad R, Sharma S N, Singh S. 1992. Fertilizer nitrogen interactions in crop production. Fert. News, 37, 75-83.

Ray D, Mandal L N, Pain A K, Mandal S K. 1973. Effect of NPK and FYM manure on the yield and nutritive value of mulberry leaf. Indian Journal of Sericulture, 12, 7-12.

Radha N V, Nagarajan P, Jayaraj S. 1988. Mineral deficiency in mulberry plants (Morus alba L.) and its effect on economic characters of silkworm, Bombyx mori L. Mad Agriculture Journal, 75, 384-390. 
International Journal of Agriculture and Environmental Research

ISSN: 2455-6939

Volume: 06, Issue: 06 "November-December 2020"

Rabbel M A. 1995. Studies On important fungal diseases of mulberry (Morus sp.) leaf in bangladesh and their control. Phd Thesis, University of Rajshahi, Bangladesh.

Rai V R. Mamtha, T. 2005. Seedling diseases of some important forest tree species and their management. In. Working Papers of the Finish Forest Research Instiatute, 11.

Sengupta A K, Kumar P, Baig M, Govindaiah. 1990. Hand book of pest and disease control of mulberry and silkworm. Escap, Thailand. pp. 88.

Seki K, Oshikane K. Research Reports Fac. 1959. Textile and Sericulture, Shinshu University.

Soltanpour P N, Workman S. 1979. Modification of the nh4hco3-dtpa soil test to omit carbon black. Communications in Soil Science and Plant Analysis, 10, 1411-1420.

Singh G S, Ram R L, Alam M, Nirmal S K. 2016. Soil test based fertilizers recommendation of NPK for Mulberry (Morus alba L.) farming in acid soils of Lohardaga. International Journal of Current Microbiology and Applied Sciences, 5(6), 392-398.

Subbiah V B, Asija G L. 1956. A rapid procedure for estimation of available nitrogen in soils. Current Science, 25, 259-260.

Vijayan K, Tikader A, Das K K, Roy B N, Pavan K T. 1996. Genotypic influence on leaf moisture content and moisture retention capacity in mulberry (Morus spp.). Bull Sericulture Research, 7, 95-98.

Venkataramu B V. 1986. Nutrient status of different mulberry varieties and its effect on growth and development of Bombyx mori L. M.Sc. (Sericulture.) Thesis, UAS, Bangalore, pp. 89

Wong S Y. 1923. The use of persulfate in the estimation of nitrogen by the arnold-gunning modification of kjeldahl's method. Journal of Biological Chemistry, 55, 427.

Yashihiko A. 1995. Sericulture in tropics. Association for international cooperation of agriculture and forestry, Tokyo, Japan.

Scriber J M, Feeny P. 1979. Growth of herbivorous caterpillars in relation to feeding specialization and to the growth form of their food plant. Ecology, 60, 829-850. 